\title{
HOMAGE TO GEORGE E. PALADE CELL PROTEIN SECRETION IN VASCULAR BIOLOGY: OVERVIEW AND UPDATES
}

\author{
George N. CHALDAKOV ${ }^{1 *}$, Luigi ALOE ${ }^{2}$, Anna KÁDÁR ${ }^{3}$, Peter GHENEV ${ }^{4}$, Marco FIORE$^{5}$, \\ Rouzha Z. PANCHEVA ${ }^{6}$, Plamen PANAYOTOV ${ }^{7}$ \\ ${ }^{*}$ Department of Anatomy and Cell Biology, and Department of Translational Stem Cell Biology, \\ Research Institute, Medical University, Varna, Bulgaria \\ ${ }^{2}$ Fondazione Iret Tecnopolo R. Levi-Montalcini, Rome, Italy \\ ${ }^{3}$ Department of Pathology, Faculty of Medicine, Semmelweis University, Budapest, Hungary \\ ${ }^{4}$ Department of Pathology, Medical University, Varna, Bulgaria, \\ ${ }^{5}$ Institute of Biochemistry and Cell Biology, Section of Neurobiology, National Research Council \\ (CNR), Rome, Italy \\ ${ }^{6}$ Department of Hygiene and Epidemiology, Faculty of Public Health, Medical University, Varna, \\ Bulgaria \\ ${ }^{7}$ Department of Cardiac Surgery, St Marina University Hospital, Varna, Bulgaria
}

*Correspondence:

George N. CHALDAKOV

chaldakov@yahoo.com

Received: 15 May 2021; Accepted: 1 June 2021; Published: 30 June 2021

\begin{abstract}
This short overview and updates expresses our brain-and-heart homage to George Emil Palade, "the most influential cell biologist ever". In his 1971 paper Palade wrote for Albert Claude, the founder of biological electron microscopic method: "Seldom has a field owed so much to a single man". Herein, we articulate the same words for George Palade, the Teacher of many generations in cell biology research and education. Accordingly, we focus on two paradigm shifts in the cell biology, namely (i) the transition from light to transmission electron microscopy in studying cell protein secretion made by George Palade, and (ii) the transition from contractile to secretory phenotype of vascular smooth muscle cells made by Maria Daria Haust followed and developed by our research group. Altogether, we argue that one of the present challenges in vascular biology is to cultivate secreto-centric thinking and thus further focusing on how we could make the vascular muscle's secretory pathways work for the benefit of human's cardiovascular health.
\end{abstract}

Keywords: George Palade, proteins, secretory pathways, rough endoplasmic reticulum, Golgi complex, microtubules, colchicine, therapy, cardiovascular diseases.

\section{Introduction}

Some people are so much known that it is sufficient to mention their initials only to recognize them:

L - Carl Linnaeus

$\mathrm{N}$ - Napoleon Bonaparte
FDR - Franklin Delano Roosevelt

JFK - John Fitzgerald Kennedy

RLM - Rita Levi-Montalcini

GEP - George Emil Palade 


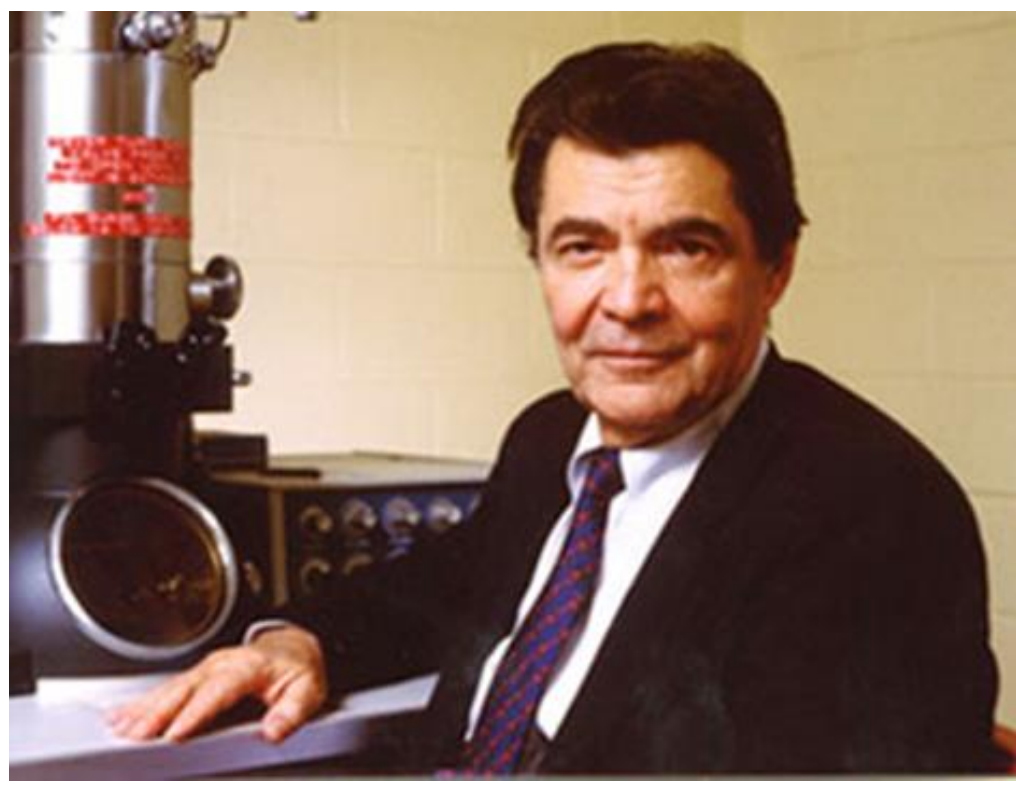

George Emil Palade (November 19, 1912 - October 7, 2008) was a Romanian-American cell biologist graduated in 1940 from the Carol Davila School of Medicine in Bucharest.

In his 1971 paper George Palade wrote for Albert Claude, the founder of biological electron microscopic method: "Seldom has a field owed so much to a single man" (Palade 1971). Herein, we, most respectfully, articulate the same words for him, the Teacher of many generations in cell biology research and education (Singer, 2003; Farquhar, 2012; Chaldakov, 2016). We, particularly one of us (GNC), learned a lot of his concept of cell protein secretion in exocrine pancreatic cells and applied (1972-1992) it to his transmission electron microscopy (TEM) studies on the secretion in vascular smooth muscle cells (VSMC).

\section{George Palade's Eureka}

- Ribosomes and polyribosmes (polysomes) - free in the cytoplasm or attached on the surface of endoplasmic reticulum's cisterns.

- Endoplasmic reticulum - smooth (without attached polysomes) or rough (with attached polysomes (Fig. 1).
- Mitochondria

- Golgi complex and Golgi-derived secretion vacuoles (granules)

- Specific granules in heart's atrial cardiomyocytes

- Plasmalemmal vesicles (caveolae) (Fig. 2)

- Weibel-Palade bodies, the structural signature of vascular endothelial cells

- The concept of cell protein secretion (Palade, 1975)

In the present brief overview and updates, we focus on two paradigm shifts in the cell biology, namely $(i)$ the transition from light microscopy to TEM in studying cell protein secretion made by George Palade, "the most influential cell biologist ever", and (ii) the transition from contractile to secretory phenotype of VSMC made by the centurial approaching Maria Daria Haust (Haust et al., 1960), the Great Lady of atherogenesis research, followed and developed by our research group (Chaldakov and Nikolov, 1975; Chaldakov et al., 1977; Chaldakov and Kádár, 1978; reviewed in Chaldakov and Vankov, 1886a, b). 


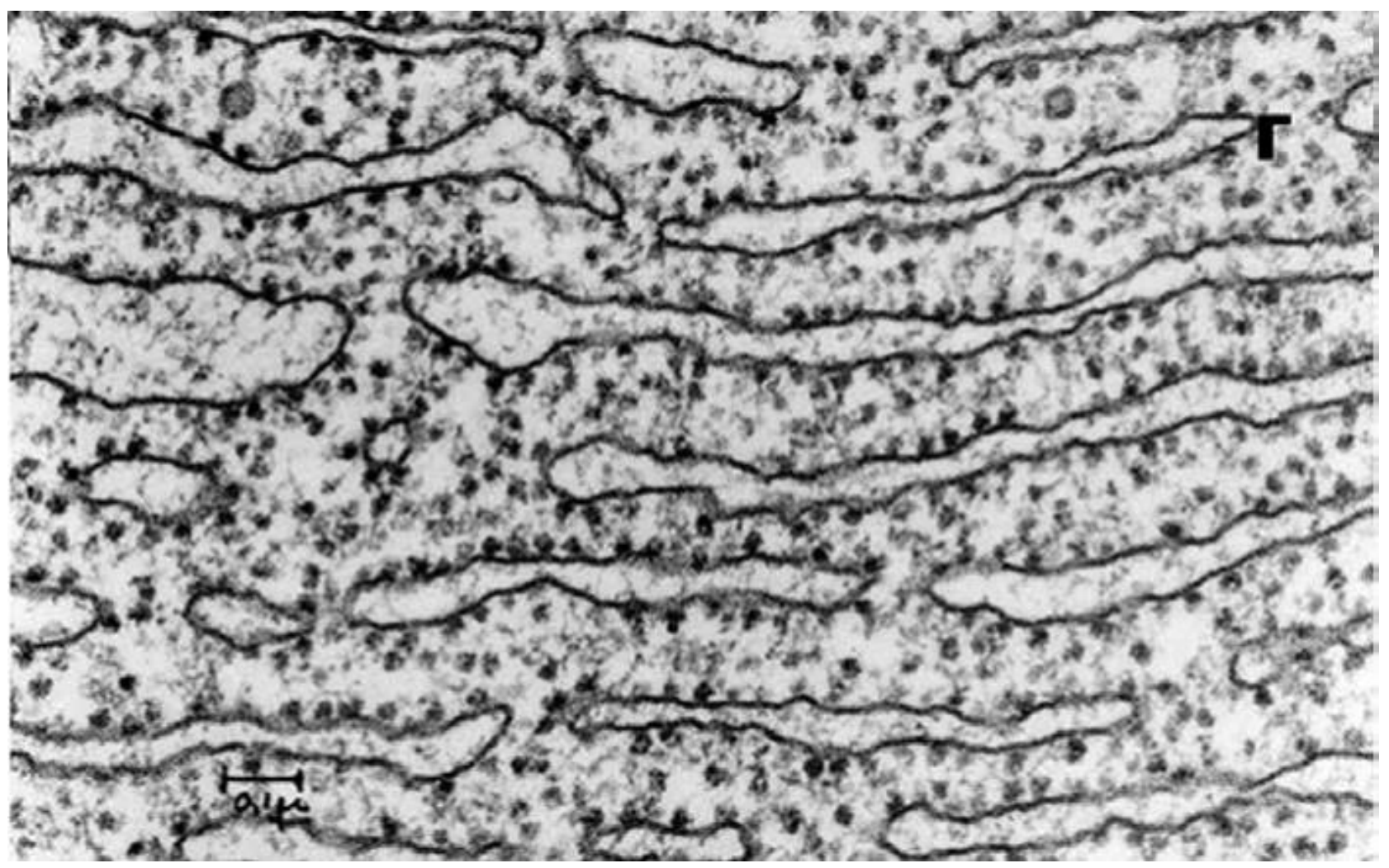

Fig. 1. TEM image of rough endoplasmic reticulum from the George E. Palade EM Collection

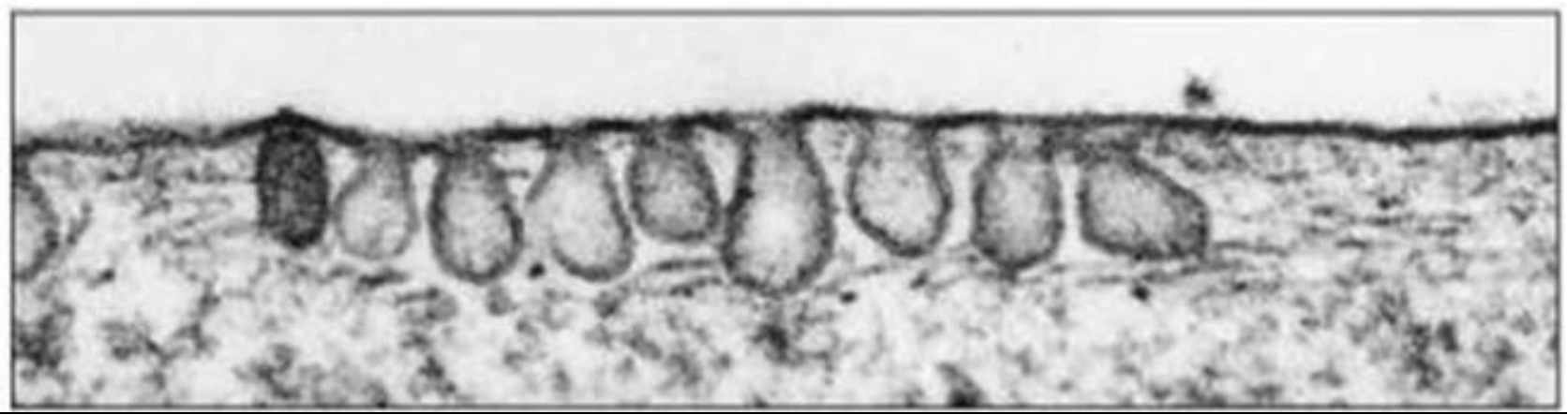

Fig. 2. TEM micrograph of plasmalemma-derived pinocytotic vesicles (Greek pino - drink, and kytos - cell) which are 50-100 nm plasmalemmal invaginations found in many cell types.

Nowadays, these vesicles are called caveolae (Latin, "little caves") coated with caveolin protein, hence, caveolin-coated vesicles. The biological importance of caveolae was enriched by recent studies using caveolin knockout mice that show severe abnormalities in the cardiovascular and other systems. Image from the George E. Palade EM Collection.

\section{Contextual background}

The secretion (synthesis, sorting, targeting, storage, and release) is a fundamental biological process in (almost) all cell types. In 1898, Camillo Golgi reported his discovery of internal reticular apparatus, a novel intracellular organelle observed in nerve cells using his silver nitrate impregnation method (Fig. 3) (reviewed in Mazzarello et al., 2009). 


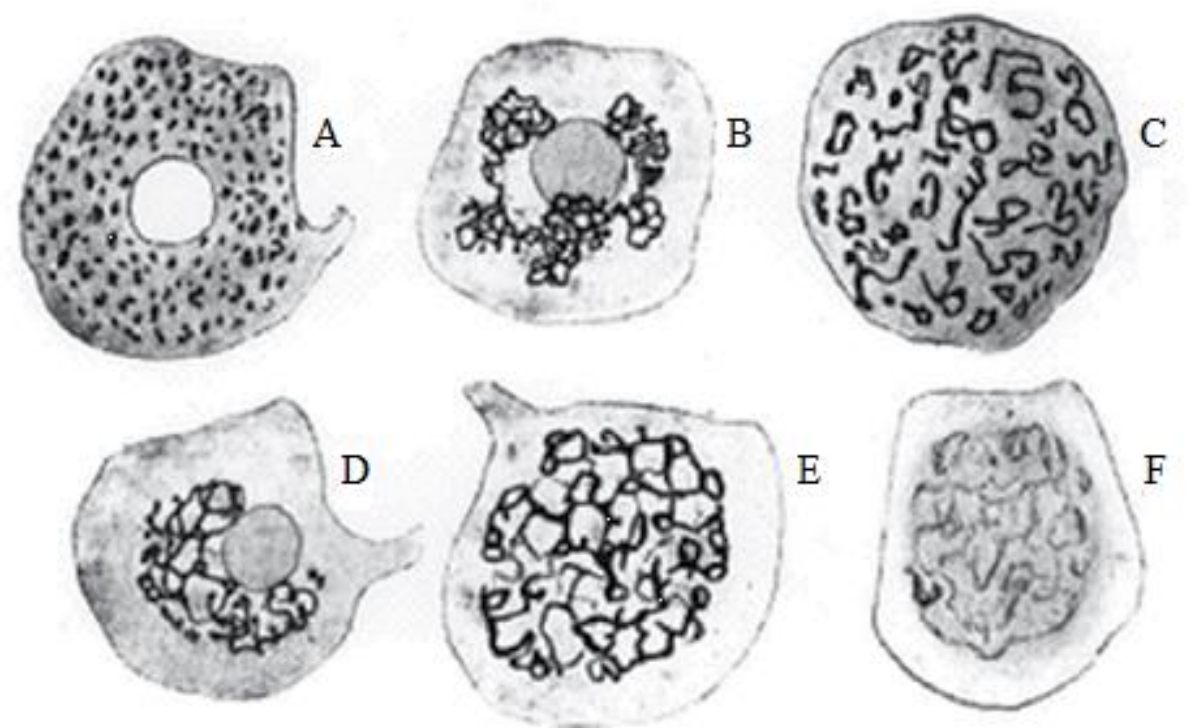

Fig. 3. Drawings of Camilo Golgi illustrating internal reticular apparatus presented in his lecture on 19 April 1898 at the University of Pavia, Pavia, Italy. This organelle was visualized by the procedure initially named by Golgi la reazione nera (Italian, "the black reaction"), later known as Golgi method of impregnation with silver salts. In the first years of 20th century internal reticular apparatus was named Golgi apparatus, latter Golgi complex - a discovery with of high scientific value in cell biology. Internal reticular apparatus' perinuclear location $(\mathbf{A}, \mathbf{B}, \mathbf{D})$ observed at different levels of cross-sections is shown $(\mathbf{A}-\mathbf{F})$.

However, the real existence of this organelle was seriously questioned until it was finally identified by TEM in the mid-1950s, mainly due to the excellent work of George Palade (Palade 1971; Farquhar and Palade, 1998; Farquhar, 2012) (Fig. 4).

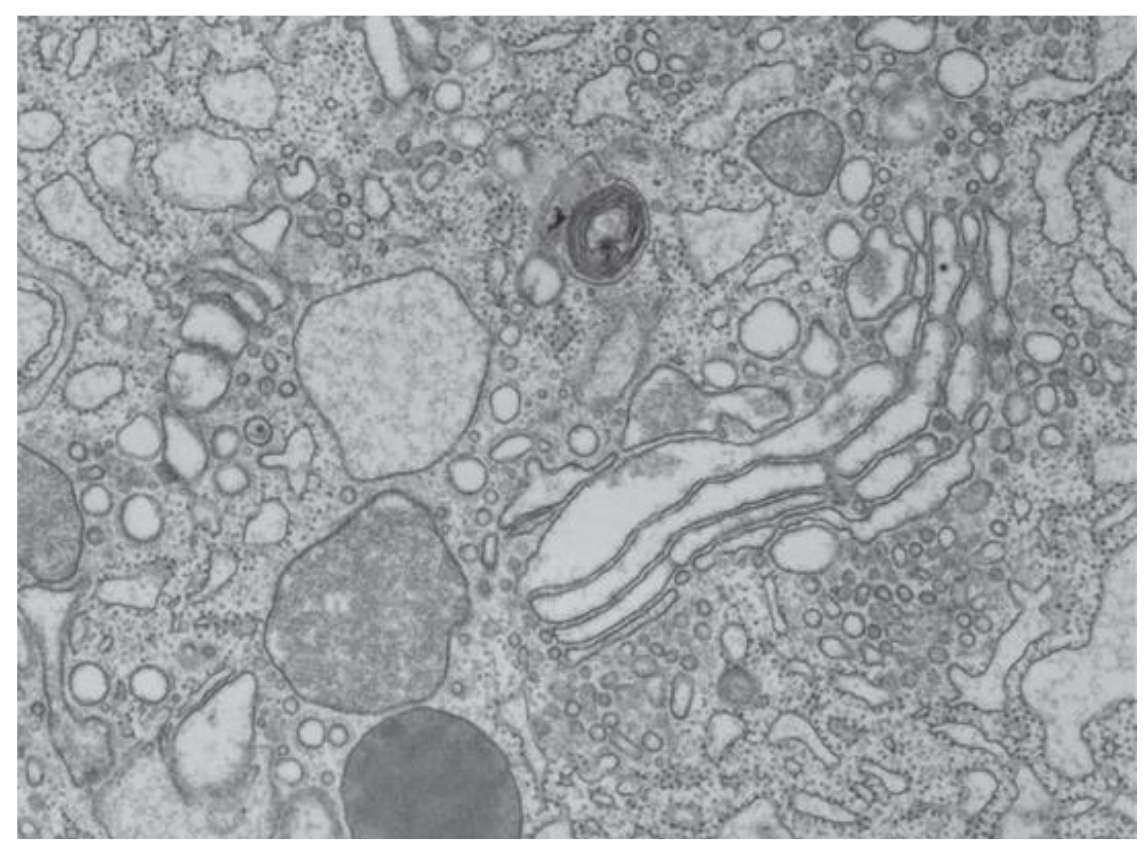

Fig. 4. TEM micrograph of the Golgi complex in a pancreatic exocrine cell. x25 000. Image from the George E. Palade EM Collection 
According to Palade's concept (Palade, regulated versus constitutive secertion), 1975) and to Günter Blobel's signal hypothesis (Blobel, 2000), the protein secretory pathway constitutes of several intracellular steps: translocation and, finally, exocytosis (Fig. 5-7) including porocytosis (Silver and Pappas, synthesis, sorting, targeting, storage (in case of 2005) mediated by porosomes (Jena, 2010).

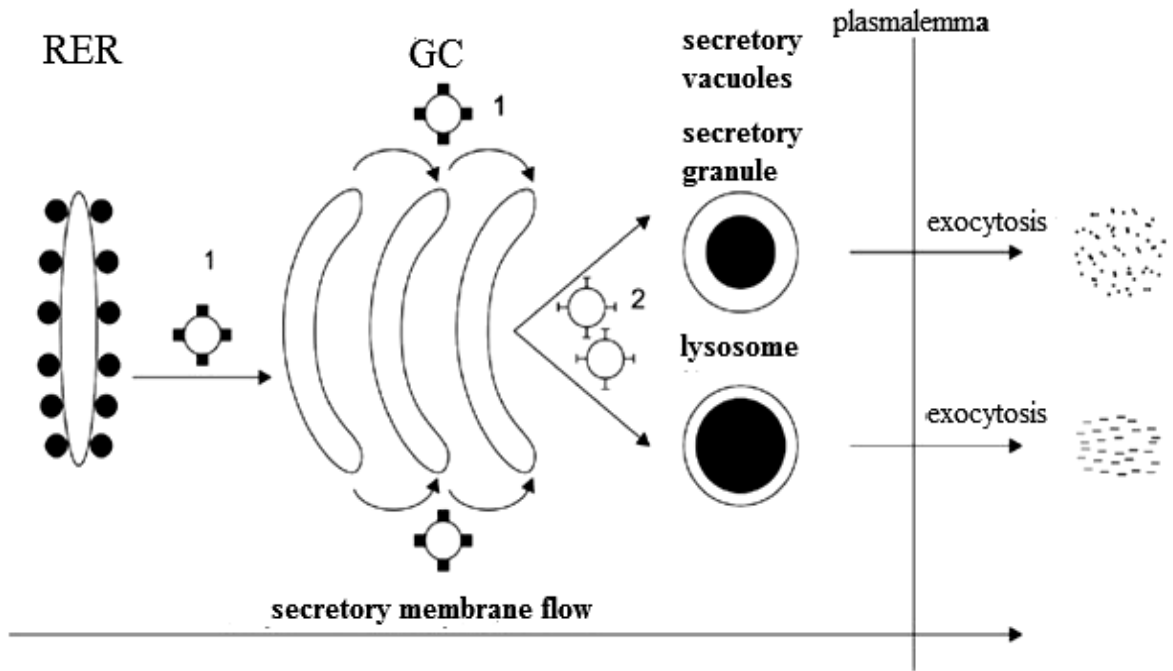

Fig. 5. Schematic representation of rough endoplasmic reticulum (RER)-Golgi pathway (secretory membrane flow). 1. COated Protein (COP II) vesicles originate from RER and translocated to Golgi complex (GC) through membrane fission-fusion way. 2. GC-derived clathrin- and adaptin-coated vesicles. Note, GC delivers both secretory vacuoles (granules) and lysosomes; their content, as exportable proteins, is discharged via exocytosis. COP I vesicles (not shown) transport proteins from cis Golgi complex back to RER, also between Golgi subcompartments, a transport termed retrograde transport, in contrast to the anterograde transport associated with COP II vesicles, which transport proteins from RER to GC. From (Chaldakov 2021)

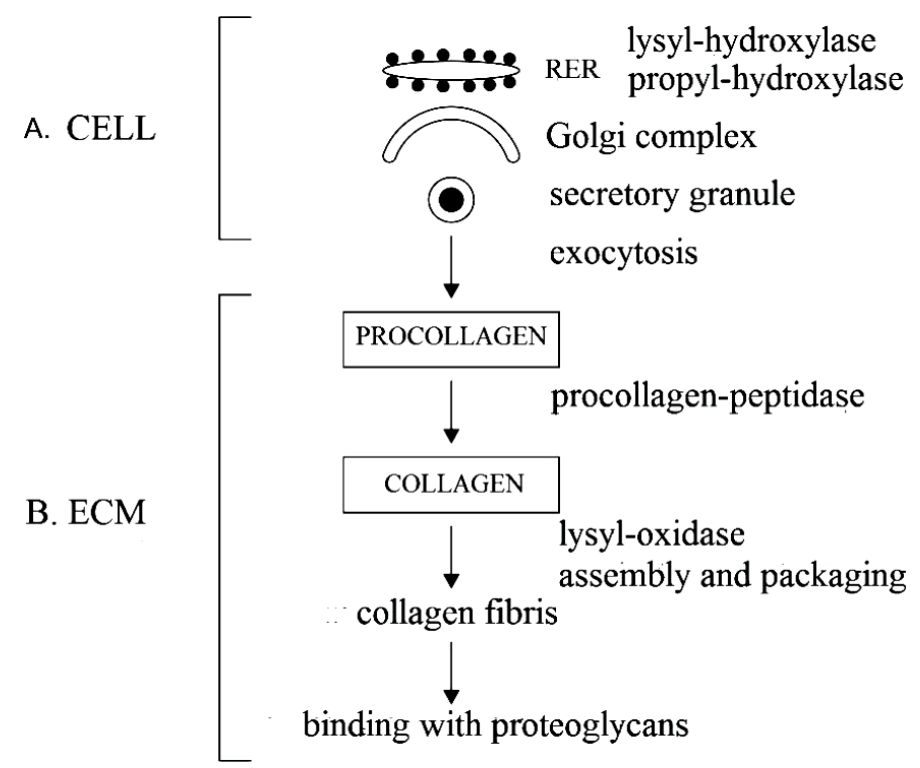

Fig. 6. Schematic representation of intra- and extracellular secretory pathways of procollagen to collagen biosynthesis. RER, rough endoplasmic reticulum; ECM, extracellular matrix. From (Chaldakov, 2021) 

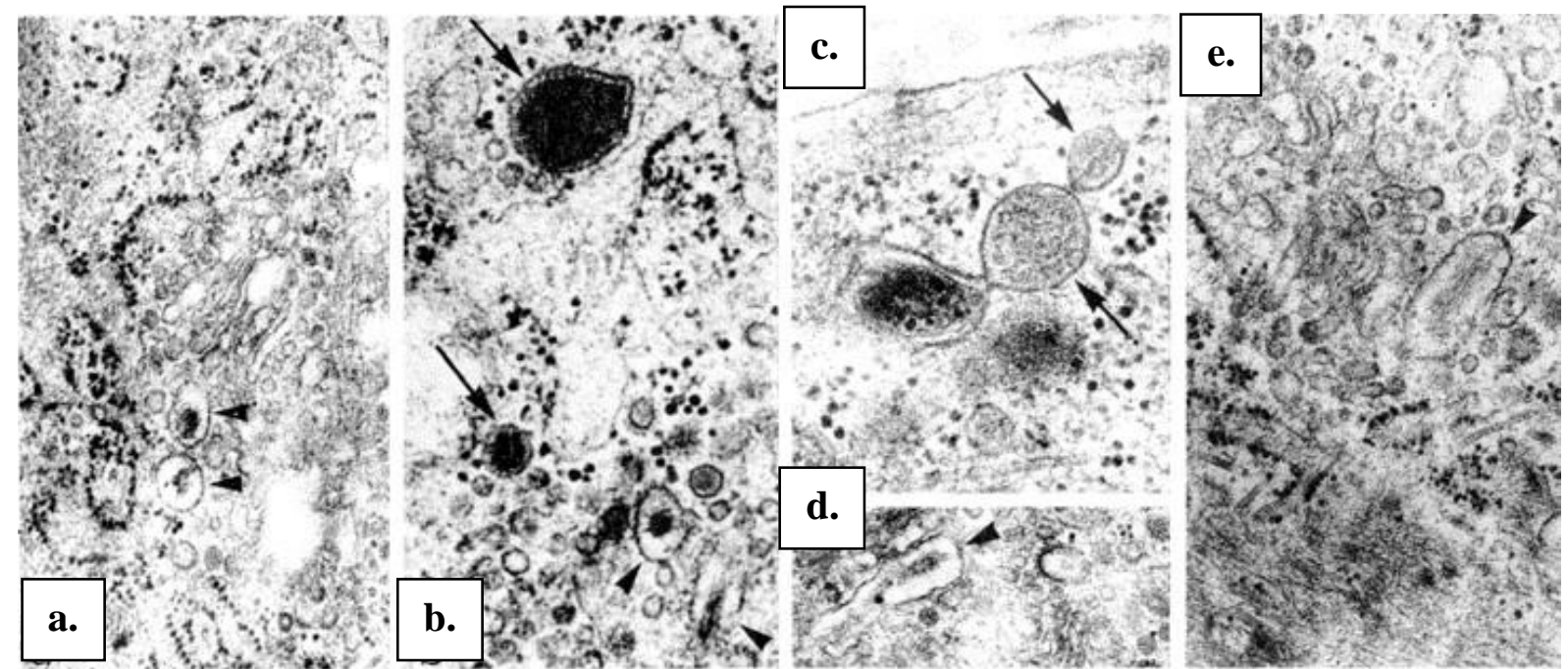

Fig. 7. TEM micrographs of secretory-state (secretory phenotype) aortic smooth muscle cells of the rabbit. a-e. Spherical-shaped (arrows) and elongated-shaped (arrowheads) secretion granules.

a-e, x20 000. From (Chaldakov and Vankov, 1986a)

In 1974, the Nobel Prize in Physiology or Medicine was awarded to Albert Claude, George Palade, and Christian de Duve "for their discoveries concerning the structural and functional organization of the cell". Then, the Chairman of the Nobel committee remarked: "The trio was largely responsible for the creation of modern cell biology". Indeed, it has been discovering a novel world of the cell, revealing membrane-bound organelles (mitochondria, caveolae, endoplasmic reticulum, Golgi complex, endosomes, lysosomes, etc) and non-membrane-bound organelles (polyribosomes, cytoskeletal filaments and microtubules, spliceosomes, proteasomes, etc). When received the Nobel prize, George Palade said: "Cell biology finally makes possible a century-old dream: that of analysis of diseases at the cellular level, the first step toward their control." This statement might be envisaged as an ideogenetic beginning of the translational research.

\section{All cells secrete proteins}

The human body could be viewed as composed of multiple types of secretory cells delivering a vast number of (neuro)peptides, cellular proteins (cytokines, chemokines, cell growth factors, adipokines, myokines, adipomyokines, osteokines, gastrokines, etc), extracellular matrix proteins, glycoproteins and proteoglycans (collagen, elastin, fibrillin, aggrecan, laminin, fibronectin, etc), also steroids and other signaling and structural molecules, which control many biological processes and functions in health and disease (Palade, 1975; Blobel, 2000; Chaldakov et al., 2003; Töre et al., 2007; Chaldakov and Fiore, 2010, Frohlich et al., 2021).

The secretory proteins are two major classes: imported and exported proteins. Accordingly, they are targeted to five loci: cytosol, organelles, nucleus, plasmalemma, and outside the cell. A large number of exported proteins are processed by the RER-Golgi complex-TGN (trans-Golgi network) route including targeting processes using signal recognition particle (SRP)-polyribosome-signal peptide (SP) receptor-mediated interactions; these latter represent the Blobel's topology concept of cell protein secretion (Blobel, 2000).

However, such a SRP-SP dependent protein secretion cannot explain the processing of SP-lacking proteins which are also exported 
such as cell growth factors and cytokines. These proteins gain access to the cell exterior via an unconventional secretory pathway, which does not use Golgi complex (Nickel, 2010). Intriguing examples of such a secretion are extracellular vesicles (also dubbed nanosomes): (i) exosomes, 30-100 nm vesicles derived from multivesicular bodies (Lai and Breakefield, 2012; Zar et al., 2020), and (ii) ectosomes (microparticles), 100-900 nm vesicles shaded from plasma membrane (Sadallah et al., 2011). Both exosomes and ectosomes carrying important bioactive molecules, e.g. DNA, mRNA, microRNA, cytokines and immunoglobulins, to communicate among cells via endo- and paracrine way, hence, collectively designated singnalosomes (Chaldakov, 2021).

Two membrane flows operate inside the cell:

i. Protein secretory membrane flow (secretory pathway) starting on free polyribosomes, followed by RER, posttranslational modification in Golgi complex, Golgi-derived vacuoles, the motor protein kinesin [a microtubule (MT)-based anterograde (+) motor] and, finally, plasmalemma, where the release of vacuole-stored proteins occurred (see Fig. 5-7). There are two different secretory pathways: regulated and constitutive (Fig. 8).

ii. endocytotic membrane flow (endocytic pathway) starting from plasmalemma and moves in the following order: coated pits, coated vesicles, caveolae, caveolosomes, early endosomes, late endosomes, MVB and lysosomes in collaboration with dynein [MT-based retrograde (-) motor protein]. It is the way of internalization of molecules (pinocytosis, potocytosis, and trogocytosis) and microbes (phagocytosis) from outside into inside of the cell.

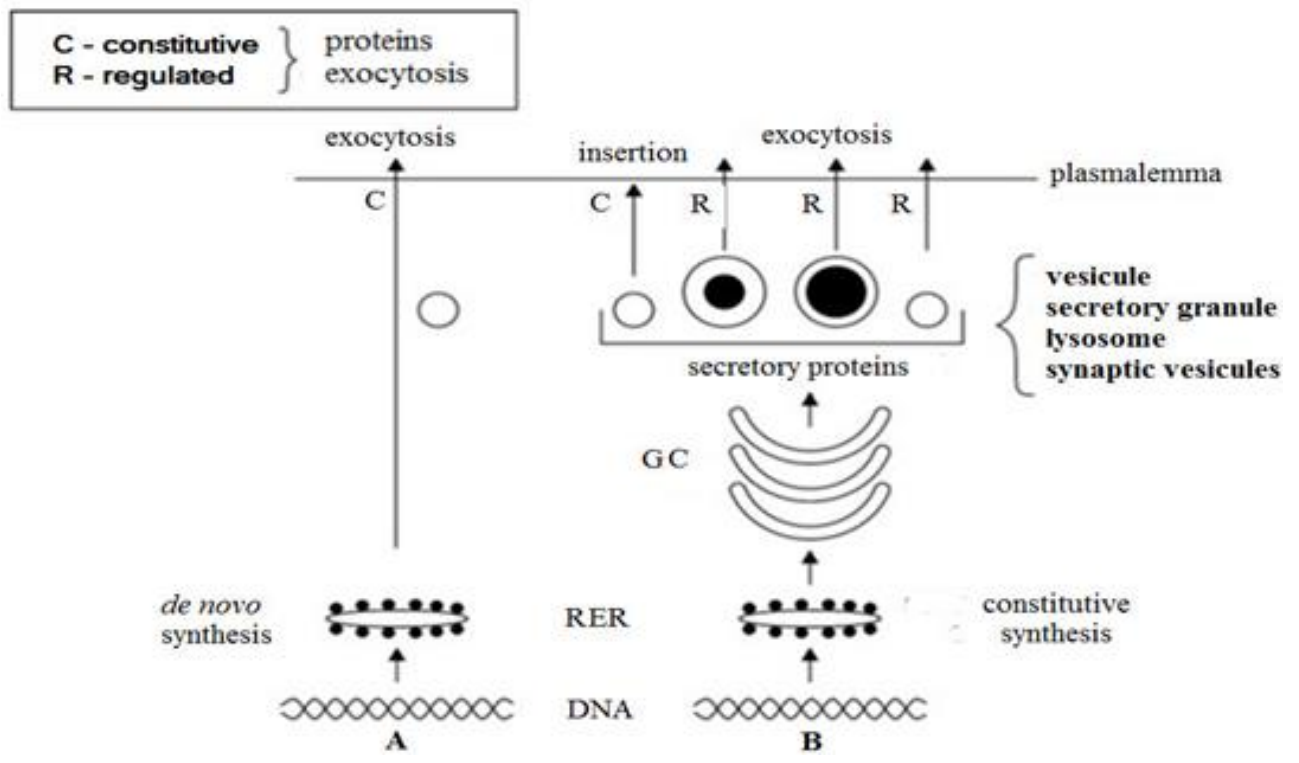

Fig. 8. Schematic illustration of constitutive (C) and regulated (R) secretory pathways. In the C pathway, secretory vacuoles continuously translocate proteins synthesized in (i) rough endoplasmic reticulum (RER) to the plasmalemma for exocytosis (A), and (ii) RER-Golgi complex (GC) for the insertion within the plasmalemma (B). In the R pathway, RER-GC synthesized proteins are stored within various types of secretory granules or vesicles until they released in response to specific signals (B). From (Chaldakov, 2021) 
Table 1 presents a summating view of "Palade dixit" about cell protein secretion.

Table 1. The intracellular protein secretory pathway

\section{PALADE DIXT}

\section{The protein secretory pathway}

\begin{tabular}{ll}
\hline $\begin{array}{l}\text { - Synthesis } \\
\text { - Post-translational } \\
\text { modification }\end{array}$ & $\begin{array}{c}\text { Rolgi complex } \\
\text { - Sorting }\end{array}$ \\
$\begin{array}{c}\text { Günter Blobel's signaling amino acid } \\
\text { sequence }\end{array}$ \\
$\begin{array}{l}\text { - Storage } \\
\text { - Transport }\end{array}$ & $\begin{array}{c}\text { Golgi complex, Secretory vacuoles } \\
\text { Microtubules, Kinesin, COP I, COP II } \\
\text { Actin filaments, Myosin II }\end{array}$ \\
- Exocytosis & Plasmalemma/Porosomes
\end{tabular}

Abbreviations: RER, rough endoplasmic reticulum; COP, coat protein, COP I and COP II vesicles, respectively.

Vascular biology: secretory phenotype smooth muscle cells

In 1960 Maria Daria Haust and colleagues (Haust et al., 1960) published their seminal article suggesting the fibrogenic potential of VSMC as related to extracellular matrix production. Since then VSMC secretion, proliferation and migration have been increasingly studied as key cellular phenomena in the initiation and development of atherosclerosis. This concept was further developed (Ross, 1999; Libby, 2021). Of note, in the last 10-15 years a new paradigm shift in the process of atherogenesis has been emerging addressing the pivotal role of the atherosclerotic plaque's fibrous cap (Ghenev et al., 2017; Chaldakov et al., 2020).

In 1973 in Heidelberg, Germany, a Symposium on The Smooth Muscle of the Artery was held. There, one of us (GNC) presented a lecture on their own TEM findings on the significance of (i) Golgi-derived secretion granules and clathrin-coated vesicles, and (ii) cytoplasmic MT in the secretory pathway of VSMC (Chaldakov and Nikolov, 1975) (Fig. 9). Based on these and related own results (cited herein), the term "secretion" was for the first time linked to VSMC functions, and it was appreciated by the vascular biology community, thus replacing the terms "modified SMC" and "synthetic SMC", which were not conceptually correct in sense of Palade's understanding of the cell protein secretion. Here is placed the great significance to find the Teacher, and to creatively follow Him.

Microtubules are essential for the secretion in vascular smooth muscle cells

It is well known that the major architectural components of cytoskeletal MT are $\alpha$ - and $\beta$-tubulins, MT-associated proteins (MAP 1-4 and tau protein) being tightly involved in the microtubulogenesis. Microtubules are essential for a variety of cellular functions, including the translocation of RER- and Golgi-derived vesicles and vacuoles during the secretory process. There are chemical substances which can disassemble already formed MT and inhibit de novo MT formation via their tubulin-binding properties, hence these agents are termed antitubulins or MT-disassembling agents, colchicine being the classical example of them (reviewed in Yanev et al., 2016; Chaldakov, 2018). 
Our colchicine study for the first time aimed at testing the possible role of MT for VSMC secretory process. The experimental rabbits were treated with a sub-antimitotic dose of colchicine aimed at the disassembly of cytoplasmic, not mitotic, MT. The VSMC of untreated rabbits showed well-developed RER and Golgi complex, and MT associated with Golgi-derived secretion granules and with cisternae of RER. Colchicine treatment affected (i) MT in a monotypic way (all VSMC contained no MT after colchicine), and (ii) Golgi complexes and RER in a dual way, resulting in two structural subpopulations of VSMC. One subpopulation displayed a significant accumulation of Golgi-derived secretion granules (Fig. 10a), whereas another showed a vacuolar dilation of RER cisternae (Fig. 10b).

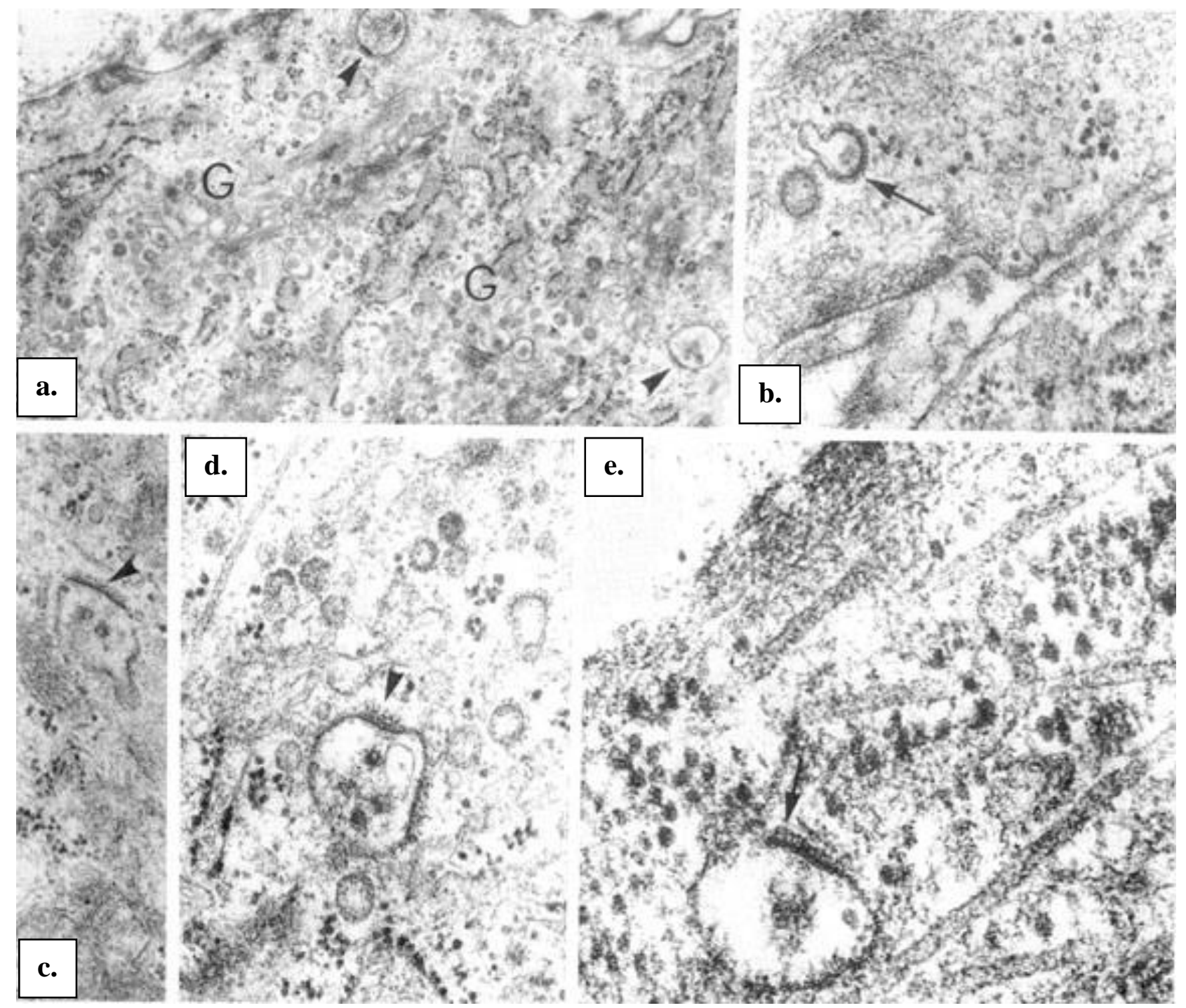

Fig. 9. Electron micrographs of secretory-state (secretory phenotype) aortic smooth muscle cells of the rabbit. a. Well developed Golgi complex (G). b-e. Vacuoles with a fuzzy (probably not clathrin) coat (arrowheads and arrows). e. Vacuole-associated microtubules. a, x11 000; b, x30 000; c, x20 000; d, x45 000; e, x80 000. From (Chaldakov and Vankov, 1986) 

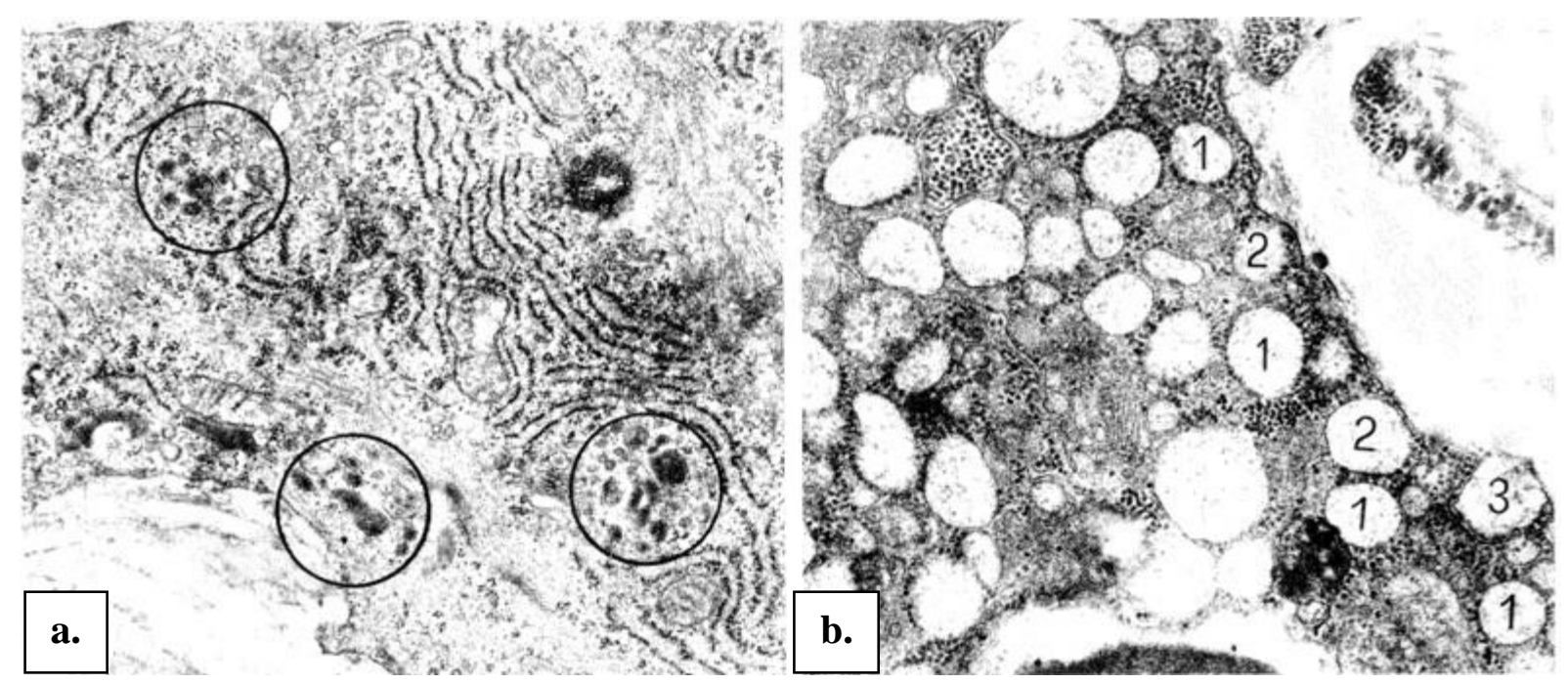

Fig. 10. Electron micrographs of secretory-state (secretory phenotype) aortic smooth muscle cells of the rabbit treated with a sub-antimitotic dose of colchicine. The cells responded to the treatment

by (a) an accumulation of secretion granules (circles), or (b) vacuolar type dilation of rough endoplasmic reticulum (RER) cisternae, some of them approaching the cell periphery $(1,2,3)$,

suggesting of a direct RER, not dependent on MT, way of exocytosis. a, b, x10 000. From (Chaldakov, 2018)

Colchicine and cardiovascular diseases: Bench-to-bedside data

Atherosclerotic cardiovascular disease and its complications (erosion and rupture of the plaque fibrous cap) lead to acute coronary syndromes, myocardial infarction or stroke. Accordingly, VSMC of the innermost media undergo phenotypic modulation towards a secretory state involved in matrix proteins production (see Fig. 6). The risk of plaque rupture is inversely correlated with the presence of secretory phenotype VSMC and collagen fibrils within the fibrous cap (Shankman et al., 2015; Ghenev et al., 2017; Wirka et al., 2019; Chaldakov et al., 2020).

Bench-to-bedside (B2B) investigations are the process of translating basic science discoveries into clinical applications. The B2B model begins with experiments in the laboratory and ends with success or failure in clinical trials.

For instance, the therapeutic use of colchicine has extended from its classical application in gouty arthritis to familial
Mediterranean fever, Behcet's disease, liver fibrosis, osteoarthritis, pericarditis, and a variety of disorders associated with the cardiovascular disease (e.g., acute coronary syndromes, myocardial infarction, atrial fibrillation, and hypertrophic cardiomyopathy it is known that the accumulation of MT in hypertrophied cardiomyocytes impedes their contraction, whereas MT disassembly by colchicine causes striking improvement in contractile function) (reviewed in Chaldakov and Vankov, 1986b).

Recently, our abovementioned colchicine results (also see Cecconi et al., 2021) gained a therapeutic appreciation in cardiovascular diseases using $0.5 \mathrm{mg} / \mathrm{day}$, low-dose colchicine (LoDoCo) therapy (Nidorf et al., 2013; Lee et al., 2016; Vaidya et al., 2017; Tardif et al., 2019).

Whatsoever, a more effective approach would be a "bench-to-bedside-to-bench" (B2B2B) as some colleagues proposed. 


\section{Conclusions}

We argue that one of the present challenges in vascular biology is to cultivate secreto-centric thinking applied to further focusing on how we could make VSMC phenotypic modulation and secretory pathways work for the benefit of human's cardiovascular health, including in thoracic aortic aneurysms related to Marfan syndrome (Xiong et al., 2008; Mullen et al., 2019).

\section{Acknowledgement}

We appreciate the valuable and stimulating discussions with our brain-and-heart friends (BHF) Maria Daria Haust, Zanka B. Jurukova, Michael S. Davidoff, Gheorghe Benga, Yukio Yamori, Takashi Fujiwara, Stanislav Yanev, Maria D. Zhelyazkova-Savova, Wale A.R. Sulaiman, Anton B. Tonchev, and Alexander K. Stoychev. Partial republishing with the agreement of the journals Biomedical Reviews and Adipobiology.

\section{Conflict of interest}

The authors have declared that there is no conflict of interest.

\section{References}

1. Blobel G (2000) Protein targeting. Biosci Rep 20:303-344.

doi: 10.1023/a:1010318832604

2. Cecconi A, Vilchez-Tschischke JP, Mateo J, Sanchez Gonzalez J, España S, et al. (2021) Effects of colchicine on atherosclerotic plaque stabilization: a multimodality imaging study in an animal model. J Cardiovasc Transl Res 14(1):150-160. doi:10.1007/s12265-020-09974-7

3. Chaldakov GN and Nikolov SD (1975) Ultrastructure of the arterial smooth muscle cell. In: Wolf S, Werthessen NT, editors. The Smooth Muscle of the Artery. New
York City, NY: Plenum Press. Adv Exp Med Biol 57:14-20.

4. Chaldakov GN, Nikolov S, Vancov V (1977) Fine morphological aspects of the secretory process in arterial smooth muscle cells. II. Role of microtubules. Acta Morphol Acad Sci Hung 25:167-174.

5. Chaldakov GN and Kádár A (1978) Microtubules in arterial smooth muscle cells in vivo and in tissue culture. An electron microscope study. In: W. Hauss, R. Wissler, R. Lehman, editors. State of Prevention and Therapy of Human Arteriosclerosis and in Animal Models. Rheinisch-Westfalische Akad. Der Wissenschaften, p. 211-231.

6. Chaldakov G (2016) GEORGE E. PALADE LECTURE. Human body as a multicrine system, with special reference to cell protein secretion: from vascular smooth muscles to adipose tissue. Adipobiology 8:6-18. doi: 10.14748/adipo.v8.2089

7. Chaldakov G, Stankulov I, Hristova M, Ghenev P (2003) Adipobiology of disease: Adipokines and adipokine-targeted pharmacology. Curr Pharm Des 9: 10231031. doi: 10.2174/1381612033455152

8. Chaldakov GN (1982) Antitubulins - a new therapeutic approach for atherosclerosis? Atherosclerosis 44:385-390.

doi: 10.1016/0021-9150(82)90013-2

9. Chaldakov GN (2018) Colchicine, a microtubule-disassembling drug, in the therapy of cardiovascular diseases. Cell Biol Int 42:1079-1084. doi: 10.1002/cbin. 10988

10. Chaldakov GN, Beltowsky J, Ghenev PI, Fiore M, Panayotov P, Rančič G, Aloe L (2012) Adipoparacrinology - vascular periadventitial adipose tissue (tunica adiposa) as an example. Cell Biol Int 36:327-330. doi: 10.1042/cbi20110422 
11. Chaldakov GN and Fiore M (2010) Human body as a multicrine gland. Adipobiology 2: 73-75. doi: 10.14748/adipo.v2.263

12. Chaldakov GN and Vankov VN (1986a) Morphological aspects of secretion in the arterial smooth muscle cell, with special reference to the golgi complex and microtubular cytoskeleton. Atherosclerosis 61: 175-192. doi: 10.1016/00219150(86)90137-1

13. Chaldakov GN and Vankov VN (1986b) Antifibrotic approach in the therapy of arterial occlusive diseases: new considerations. In: G. Trubestein, editor. Conservative Therapy of Arterial Occlusive Disease. Stuttgart, New York, Georg Thieme Verlag, p. 224-226

14. Chaldakov GN, Zhelyazkova-Savova MD, Panayotova D, Fiore M, Yanev S (2020) Phenotypic modulation of smooth muscle cells and matrix metalloproteinases as targets for atherosclerotic plaque stabilization. Biomed Rev 31: 49-60. doi: 10.14748/bmr.v31.7704

15. Chaldakov GN (2021) Principles of Cell and Tissue Biology (in press).

16. Farquhar MG (2012) A Man for all seasons: Reflections on the life and legacy of George Palade. Ann Rev Cell Dev Biol 28: 1-28. doi: 10.1146/annurev-cellbio101011-155813

17. Farquhar MG and Palade GE (1998) The Golgi apparatus: 100 years of progress and controversy. Trends Cell Biol 8:2-10. doi: 10.1016/S0962-8924(97)01187-2

18. Frohlich J, Chaldakov GN, Vinciguerra M (2021) Cardio- and neurometabolic adipobiology: Consequences and implications for therapy. Int J Mol Sci 22: 4137. doi: 10.3390/ ijms22084137

19. Ghenev PI, Aloe L, Kisheva AR, Singh M, Panayotov P, Fiore M, et al. (2017) QUO VADIS, ATHEROGENESIS? Part 1. Smooth muscle cell secretion - how foe becomes friend in the fight against the atherosclerotic plaque. Biomed Rev 28:134-138.

20. Haust MD, More RH, Movat HZ (1960) The role of smooth muscle cells in the fibrogenesis of arteriosclerosis. Am J Pathol 37:377-389.

21. Jena BP (2010) Porosome: the universal secretory portal in cells. Biomed Rev 21: 115. doi: $10.14748 /$ bmr.v21.42

22. Lai CP and Breakefield XO (2012) Role of exosomes/microvesicles in the nervous system and use in emerging therapies. Front Physiol 3: 228. doi: 10.3389/fphys.2012.00228

23. Lee JZ, Singh N, Howe CL, Low S-W, Huang JJ, Ortega G, et al. (2016) Colchicine for prevention of post-operative atrial fibrillation. A meta-analysis. J Am Coll Cardiol Clin Electrophyisol 2(1): 7885. doi: https://doi.org/10.1016/j.jacep.2015.09.016

24. Libby P (2021) Inflammation in atherosclerosis - No longer a theory. Clin Chem 67:131-142. doi:10.1093/clinchem/hvaa275

25. Mazzarello P, Garbarino C, Calligaro A (2009) How Camillo Golgi became "the Golgi". FEBS Lett 583: 3732-3737. doi: 10.1016/j.febslet.2009.10.018

26. Mullen M, Jin XY, Child A, Stuart AG, Dodd M, Aragon-Martin JA, et al. (2019) Irbesartan in Marfan syndrome (AIMS): a double-blind, placebo-controlled randomised trial. Lancet 394: 2263-2270. doi: 10.1016/S0140-6736(19)32518-8

27. Nickel W (2010) Pathways of unconventional protein secretion. Curr Opin Biotechnol 21: 621-626. doi: 10.1016/j.copbio.2010.06.004

28. Nidorf SM, Eikelboom JW, Budgeon CA, Thompson PL (2013) Low-dose colchicine for secondary prevention of cardiovascular 
disease. J Am Coll Cardiol 61(4):404-410. doi: $10.1016 /$ j.jacc.2012.10.02

29. Palade G (1975) Intracellular aspects of the process of protein synthesis. Science 189: 347-358. doi: 10.1126/science.1096303

30. Palade GE (1971) Albert Claude and the beginnings of biological electron microscopy. J Cell Biol 50: 5d-19d. doi: 10.1083/jcb.50.1.5d

31. Ross R (1999) Atherosclerosis - An inflammatory disease. N Engl J Med 340: 115-126.

doi: 10.1056/nejm199901143400207

32. Sadallah S, Eken C, Martin PJ, Schifferli JA (2011) Microparticles (ectosomes) shed by stored human platelets downregulate macrophages and modify the development of dendritic cells. J Immunol 186: 65436552. doi: 10.4049/jimmunol.1002788

33. Shankman LS, Gomez D, Cherepanova OA, Salmon M, Alencar GF, Haskins RM, et al. (2015) KLF4-dependent phenotypic modulation of smooth muscle cells has a key role in atherosclerotic plaque pathogenesis. Nat Med 21(6): 628-637. doi: 10.1038/nm.3866

34. Silver R and Pappas G (2005) Secretion without membrane fusion: Porocytosis. Anat Rec B New Anat 282: 18-37. doi: 10.1002/ar.b.20050

35. Singer MV (2003) Legacy of a distinguished scientist: George E. Palade. Pancreatology 3:518-519. doi: $10.1159 / 000076328$

36. Tardif J-C, Kouz S, Waters DD, Bertrand OF, Diaz R, Maggioni AP, et al. (2019)
Efficacy and safety of low-dose colchicine after myocardial infarction. N Engl J Med 381(26):2497-2505.

doi: 10.1056/NEJMoa1912388

37. Töre F, Tonchev A, Fiore M, Tunçel N, Atanassova P, Aloe L, et al. (2007) From adipose tissue protein secretion to adipopharmacology of disease. Immun Endoc Metab Agents Med Chem 7: 149155. doi: $10.2174 / 187152207780363712$

38. Vaidya K, Arnott C, Martínez GJ, Ng B, McCormack S, Sullivan DR, et al. (2017) Colchicine therapy and plaque stabilization in patients with acute coronary syndrome. $\mathrm{J}$ Am Coll Cardiol Img. doi: https://doi.org/10.1016/j.jcmg.2017.08.013 39. Wirka RC, Wagh DA, Paik DT, et al. (2019) Atheroprotective roles of smooth muscle cell phenotypic modulation and the TCF21 disease gene as revealed by singlecell analysis. Nat Med 25(8): doi:10.1038/s41591-019-0512-5

40. Xiong W, Knispel RA, Dietz HC, Ramirez F, Baxter BT (2008) Doxycycline delays aneurysm rupture in a mouse model of Marfan syndrome. J Vasc Surg 47(1): 166172. doi:10.1016/j.jvs.2007.09.016

41. Yanev S, Fiore M, Hinev A, Ghenev PI, Hristova MG, Panayotov P, et al. (2016) From antitubulins to trackins. Biomed Rev 27:59-67.

42. Zar M, Amadio P, Campodonico J, et al. (2020) Exosomes in cardiovascular diseases. Diagnostics 10:943. doi:10.3390/diagnostics1011094 